INTERNATIONAL

FOOD POLICY

RESEARCH

INSTITUTE

IFPRI

IFPRI Discussion Paper 01485

December 2015

\title{
US Maize Data Reveals Adaptation to Heat and Water Stress
}

Timothy S. Thomas

Environment and Production Technology Division 


\section{INTERNATIONAL FOOD POLICY RESEARCH INSTITUTE}

The International Food Policy Research Institute (IFPRI), established in 1975, provides evidence-based policy solutions to sustainably end hunger and malnutrition and reduce poverty. The Institute conducts research, communicates results, optimizes partnerships, and builds capacity to ensure sustainable food production, promote healthy food systems, improve markets and trade, transform agriculture, build resilience, and strengthen institutions and governance. Gender is considered in all of the Institute's work. IFPRI collaborates with partners around the world, including development implementers, public institutions, the private sector, and farmers' organizations, to ensure that local, national, regional, and global food policies are based on evidence. IFPRI is a member of the CGIAR Consortium.

\section{AUTHOR}

Timothy S. Thomas (tim.thomas@cgiar.org) is a research fellow in the Environment and Production Technology Division of the International Food Policy Research Institute, Washington, DC.

\section{Notices}

1. IFPRI Discussion Papers contain preliminary material and research results and are circulated in order to stimulate discussion and critical comment. They have not been subject to a formal external review via IFPRI's Publications Review Committee. Any opinions stated herein are those of the author(s) and are not necessarily representative of or endorsed by the International Food Policy Research Institute.

2. The boundaries and names shown and the designations used on the map(s) herein do not imply official endorsement or acceptance by the International Food Policy Research Institute (IFPRI) or its partners and contributors.

Copyright 2015 International Food Policy Research Institute. All rights reserved. Sections of this material may be reproduced for personal and not-for-profit use without the express written permission of but with acknowledgment to IFPRI. To reproduce the material contained herein for profit or commercial use requires express written permission. To obtain permission, contact ifpri-copyright@cgiar.org. 


\section{Contents}

Abstract $\quad$ V

Acknowledgments $\quad$ vi

1. Introduction 1

2. The Approach Used 3

3. Important Statistical Results 5

4. Estimating Climate Impact on Maize $\quad 9$

5. Concluding Remarks 10

References 11 


\section{Tables}

1.1 Percentage change in yield due to climate change only between 2000 and 2050 for global rainfed maize

1.2 Percentage change in yield due to climate change only between 2000 and 2050 for rainfed maize, United States

3.1 Regression results for log of rainfed maize yield

3.2 Regression results for log of rainfed maize yield with interaction of time trend and weather variables

4.1 Projected yield changes from regression estimates, 2000 to 2050 


\begin{abstract}
Heat is a serious barrier to maize productivity increases, and heat is expected to rise as a result of climate change. Using county-level annual yields for rainfed maize for 2,616 US counties from 1980 to 2010, we conduct a multivariate, nonparametric yield response analysis to weather, maize price, and time trend to project climate impact on maize and to compare with climate projections from crop models. When we compare with climate impacts predicted by biophysical models, we find that our analysis tends to support the most pessimistic of the biophysical model projections for climate change.

We also demonstrate that growth in maize yields in the United States between 1980 and 2010 was higher under high temperatures than under moderate temperatures, with yields growing 20.2 percent faster when the mean daily maximum temperature for the warmest month ranged from 34 to 35 degrees Celsius instead of 28 to 29 degrees. Similarly, we find that US maize has become more tolerant of lower rainfall levels, with yields growing 15.9 percent faster between 1980 and 2010 when rainfall is below 250 millimeters in the first four months of the growing period compared with when it is between 400 and 450 millimeters (the optimal amount of rainfall). This suggests that significant adaptation to current and future effects of climate change is already taking place for US maize.
\end{abstract}

\title{
Keywords: climate impacts | climate change adaptation | agricultural productivity | model intercomparison panel analysis
}




\section{ACKNOWLEDGMENTS}

I would like to thank Ricky Robertson for his help with providing bioeconomic results from DSSAT and for providing the climate model inputs which I used. I would like to thank Mark Rosegrant, Keith Wiebe, Sherman Robinson, Vince Smith, Lillian Anderson, Vijay Nazareth, Daniel Mason-D'Croz, and other colleagues in the Environment and Production Technology Division at IFPRI, for their comments on earlier versions of this paper or giving helpful feedback and suggestions following a presentation of these results at a seminar.

\section{Funding}

This work was undertaken as part of the Global Futures and Strategic Foresight (GFSF) program, a CGIAR initiative led by the International Food Policy Research Institute (IFPRI) and funded by the Bill \& Melinda Gates Foundation (BMGF); the CGIAR Research Program on Policies, Institutions, and Markets (PIM); and the CGIAR Research Program on Climate Change, Agriculture, and Food Security (CCAFS). Additional funding for work on the International Model for Policy Analysis of Agricultural Commodities and Trade (IMPACT) water models was provided by the CGIAR Research Program on Water, Landscapes, and Ecosystems. This paper has not gone through IFPRI's standard peer-review procedure. The opinions expressed here belong to the author, and do not necessarily reflect those of GFSF, PIM, IFPRI, CCAFS, or CGIAR. 


\section{INTRODUCTION}

We must understand the potential impact of climate change on agriculture if we are to continue to improve food security and reduce hunger, malnutrition, and poverty. Researchers have been studying the impact of climate change on agriculture for more than two decades (Rosenzweig et al. 2014; Rosenzweig and Parry 1994), though they have not arrived at a consensus as to the magnitude of the impact. Some models look only at the direct impact on agricultural productivity (Rosenzweig et al. 2014; Müller and Robertson 2014), while others incorporate productivity changes into economic models to get a fuller picture of the impact of climate change taking into account things such as technological improvements in agriculture and substitutions that take place on both the supply and demand side as a result of changes in prices, productivity, population, and gross domestic product (Nelson et al. 2014; Nelson et al. 2013; Rosegrant, Agcaoili-Sombilla, and Perez 1995; Nelson et al. 2009; Nelson et al. 2010; Fischer, Shah, and Velthuizen 2002).

The Global Gridded Crop Model Intercomparison (GGCMI) project compared projections of several different biophysical process-based and agroecosystem models (Rosenzweig et al. 2014), based on common daily weather data for each general circulation model (GCM). Yields were computed at each half-degree gridcell for a reference period (1980-2010) and future periods. We tabulated their gridded datasets (Rosenzweig et al. 2014; Elliott et al. 2015) using mean crop area per gridcell from 2005 to 2007 as a weight (You and Wood 2006; You, Wood, and Wood-Sichra 2006, 2009, 2014). Of the three major grains of the world (wheat, maize, and rice), maize is projected to face the highest losses from climate change, so we choose to focus on that here.

Table 1.1 presents the results for those tabulations for global rainfed maize, taking into account $\mathrm{CO}_{2}$ fertilization. Each row is for a different crop modeling team (pDSSAT, Elliott et al. 2013, Jones et al. 2003; EPIC, Williams and Sharpley 1990, Williams 1995, Gassman et al. 2004, Izaurralde et al. 2006; gEPIC, Jones et al. 2003, Williams and Sharpley 1990, Williams 1995, Liu et al. 2007; PEGASUS, Deryng et al. 2011; LPJmL, Fader et al. 2010, Bondeau et al. 2007, Waha et al. 2012; LPJ-GUESS, Deryng et al. 2011, Smith, Prentice, and Sykes 2001, Lindeskog et al. 2013; GAEZ-IMAGE, Leemans and Solomon 1993, Bouwman et al. 2006). Each column represents a different GCM (GFDL-ESM2M, Dunne et al. 2012, Dunne et al. 2013; HadGEM2-ES, Collins et al. 2011, Martin et al. 2011; IPSLCM5A-LR, Dufresne et al. 2013; MIROC-ESM-CHEM, Sakamoto et al. 2012; NorESM1-M, Iversen et al. 2013). For the HadGEM GCM, we calculated that despite using the same weather data, the seven modeling teams projected change in global rainfed maize yield between 2000 and 2050 to range between a loss of 27.4 percent (PEGASUS, Izaurralde et al. 2006) and a gain of 9.6 percent (LPJ-GUESS, Deryng et al. 2011, Bondeau et al. 2007, Waha et al. 2012 ).

Table 1.1 Percentage change in yield due to climate change only between 2000 and 2050 for global rainfed maize

\begin{tabular}{lrrrrr}
\hline & \multicolumn{5}{c}{ Climate model } \\
\cline { 2 - 6 } Crop model & GFDL & HadGEM & IPSL & MIROC & NorESM \\
\hline pDSSAT & 2.1 & -6.5 & 0.2 & -4.3 & -0.3 \\
EPIC & 4.0 & -10.2 & -7.1 & -10.2 & -5.7 \\
gEPIC & 0.1 & -3.3 & -1.7 & -4.8 & -4.9 \\
PEGASUS & -12.4 & -27.4 & -19.1 & -20.4 & -7.7 \\
LPJmL & 6.4 & 1.5 & 1.1 & -0.4 & 3.1 \\
LPJ-GUESS & 7.8 & 9.6 & 12.3 & 8.9 & 11.9 \\
GAEZ-IMAGE & 2.9 & 1.6 & 3.7 & 2.6 & 3.5 \\
\hline
\end{tabular}

Sources: Rosenzweig et al. (2014); Elliot et al. (2015).

Note: This assumes RCP8.5. 
In a similar experiment with essentially the same weather data (though processed somewhat differently) but without $\mathrm{CO}_{2}$ fertilization (Müller and Robertson 2014), global maize yields from two crop models were computed to drop by 37.6 percent (DSSAT, Jones et al. 2003) and 9.9 percent (LPJmL, Fader et al. 2010, Bondeau et al. 2007, Waha et al. 2012) for the HadGEM GCM, and 33.9 percent and 14.2 percent, respectively, for the IPSL GCM.

The United States is responsible for 35 percent of global maize production (FAO 2014), and within the United States, 84 percent of maize production is rainfed (You and Wood 2006; You, Wood, and Wood-Sichra 2006, 2009, 2014). Therefore, the impact of climate change on US maize production has implications for global food security, and we focus mostly on US rainfed maize for the remainder of this paper. Table 1.2 shows our tabulations of the GGCMI results for the United States. For the HadGEM GCM, yield changes range from a loss of 38.7 percent to a gain of 16.0 percent.

Table 1.2 Percentage change in yield due to climate change only between 2000 and 2050 for rainfed maize, United States

\begin{tabular}{lrrrrr}
\hline & \multicolumn{5}{c}{ Climate model } \\
\cline { 2 - 6 } Crop model & \multicolumn{1}{c}{ GFDL } & HadGEM & \multicolumn{1}{c}{ IPSL } & MIROC & NorESM \\
\hline pDSSAT & 1.7 & -11.9 & 1.1 & -8.3 & -4.2 \\
EPIC & 16.5 & -38.7 & -12.7 & -30.9 & -18.4 \\
gEPIC & 0.6 & 1.3 & 3.5 & -6.3 & -9.9 \\
PEGASUS & -12.1 & -35.5 & -16.0 & -21.3 & -8.5 \\
LPJmL & 10.7 & 3.3 & 7.5 & 2.5 & 4.2 \\
LPJ-GUESS & 11.6 & 16.0 & 19.2 & 14.9 & 22.3 \\
GAEZ-IMAGE & 5.3 & 2.1 & 1.3 & -2.0 & 2.6 \\
\hline
\end{tabular}

Sources: Rosenzweig et al. (2014); Elliot et al. (2015).

Note: This assumes RCP8.5.

With such a wide range of projections for climate impact on both US and global maize production, policymakers may find it difficult to develop any kind of strategy for adapting to climate change. To provide additional evidence to determine which projection is more likely to occur, we compare these crop model results to a statistical analysis of historical data (Dell, Jones, and Olken 2014; Miao, Khanna, and Huang 2015; Schlenker and Roberts 2009; Lobell, Schlenker, and Costa-Roberts 2011; Lobell and Burke 2010; Lobell et al. 2011; Choi and Helmberger 1993).

This approach has several advantages over crop modeling: it is tied directly to real data; it can be used for crops that are not important enough to develop detailed crop models for; and it allows for some adaptation (since it measures actual yields produced by farmers over many years, reflecting adaptations they have made). We use the statistical results from our analysis to compute the impact of climate change on maize in the United States, and then extrapolate the results to predict the impact of climate change on global maize productivity.

In addition to making predictions for the impact of climate change on maize yields, we test to see whether yield response to temperature and precipitation has shifted over the 1980-2010 period. We find a very strong statistical indication that it has shifted over that period, suggesting that US agriculture, at least for rainfed maize, is already adapting to climate change - or at least to the kind of stresses from weather that are expected to be encountered with climate change: higher temperatures and some years with lower rainfall. 


\section{THE APPROACH USED}

We use US county-level data on maize yields for 2,616 counties for the 1980-2010 period from USDANASS (USDA-NASS 2015), being careful to exclude irrigated maize. We combine the data with values aggregated over time of daily temperature and precipitation data from the AgMERRA dataset (Ruane, Goldberg, and Chryssanthacopoulos 2015), also for 1980 to 2010, focusing on values during the cropping season. AgMERRA is a gridded dataset at a quarter-degree resolution, and we take the values from AgMERRA that are located at the geographical center of each county. To know when the cropping season is, we use data from the SAGE global cropping calendar (Sacks et al. 2010).

Because one of our objectives was to make the model simple enough to project yields into the future under climate change, we hoped to discover a small number of summary weather statistics from the daily data that would still give reasonable predictive accuracy. We began with monthly values for rainfall, mean daily maximum temperature, and mean daily minimum temperature-values that are readily available for most GCMs. With further testing, we settled on two weather indicators: mean daily maximum temperature for the warmest month out of three months (second to fourth month of the growing season); and the combined rainfall from the first four months of the growing season.

We decided to use fixed-effects panel regressions similar to other studies (Dell, Jones, and Olken 2014; Miao, Khanna, and Huang 2015; Schlenker et al. 2009; Lobell, Schlenker, and Costa-Roberts 2011), since the fixed effect controls for variables that are difficult to measure such as soil type and the costs of getting inputs and crops to and from the market. We chose the log of county yield as the dependent variable. For explanatory variables, we used a nonparametric version of the two weather variables already mentioned, as well as a time trend and the log of maize price at the state level.

The state-level expected maize price was imputed before running the main regression to take advantage of the ideal expected price of maize - the futures price of maize (Choi and Helmberger 1993; Barchart 2015) — modified by observed spatial variation of USDA-NASS (2015) data on actual prices received by farmers by state (Miao, Khanna, and Huang 2015).

A number of studies have used regressions of weather variables on maize yields. Dell, Jones, and Olken (2014) provide a thorough review of panel data models used for a broad class of problems that have dependent variables that include yields but are not limited to the agricultural sector. Miao, Khanna, and Huang (2015) is one of the most recent analyses that uses yield regressions, including the same county data that we do here, but slightly offset (1977 to 2007). The authors endeavored to include both input and output prices in their analysis. They use growing degree days, overheat days, and monthly temperature deviations instead of a more direct measure for actual temperatures, which makes their analysis difficult to compare directly with the approach we use here. However, they projected a productivity decline of 25.1 percent plus or minus 13.9 percent by 2041-2060 (comparable to what we call "2050" here in this paper) for RCP8.5 and HadGEM-ES GCM, which is one of the models we use in this study.

Schlenker and Roberts (2009), using the same county data (though for 1950 to 2005), discover that maize yields increase up to 29 degrees Celsius $\left({ }^{\circ} \mathrm{C}\right)$, then decline as temperatures rise higher. They use a nonparametric form for temperature that has the number of days during the growing season spent in each $1{ }^{\circ} \mathrm{C}$ interval. They find this method reduces the root-mean-square error over parametric approaches. They predict that in the climate of 2020-2049 there will be a 30 percent yield impact assuming a highemission scenario (A1F1) and Hadley III climate model. They evaluated whether there was any improvement in maize's ability to withstand heat, and they failed to find any, though they did this by breaking the dataset into two groups, 1950-1977 and 1978-2005.

Lobell et al. (2011) use maize data from across the continent of Africa that come from trial plots. They found that using $30^{\circ} \mathrm{C}$ as a critical threshold, each degreed day above the threshold reduces yields by 1 percent when there is sufficient water, and by 1.7 percent in drought conditions.

Lobell, Schlenker, and Costa-Roberts (2011) used country-level data on temperature and precipitation to show that climate changes between 1980 and 2008 reduced maize yields by 3.8 percent. 
Lobell and Burke (2010) tested the ability of statistical models to project future yield responses by using simulated yields from a maize crop model, using in some cases a quadratic form with temperature and precipitation. They found that at broader geographical scales, performance of statistical models was much better than at individual sites.

Finally, in one of the earliest attempts to estimate this type of equation, Choi and Helmberger (1993) used only deviation from normal precipitation as a weather variable for maize, though they did use temperature, as well, for wheat. 


\section{IMPORTANT STATISTICAL RESULTS}

Table 3.1 shows results for the simple model, in which (except for the first and last categories) rainfall is divided into 50 -millimeter intervals and temperature is divided into $1{ }^{\circ} \mathrm{C}$ ranges. The only difference between the two regressions reported in Table 3.1 is that the second one includes the log of maize price. Economics suggests that other parameter estimates could be biased if price is omitted from the regression (Miao, Khanna, and Huang 2015), but we see that even though the statistical significance of the price variable is high, none of the other parameters (except the intercept) is very different between the two regressions (which we confirmed with a statistical test on the difference of each pair).

Table 3.1 Regression results for log of rainfed maize yield

\begin{tabular}{|c|c|c|c|c|c|c|}
\hline \multirow[b]{2}{*}{ Variable } & \multicolumn{3}{|c|}{ Regression 1} & \multicolumn{3}{|c|}{ Regression 2} \\
\hline & Coefficient & \multicolumn{2}{|c|}{$\begin{array}{l}\text { Standard } \\
\text { error }\end{array}$} & Coefficient & \multicolumn{2}{|c|}{$\begin{array}{l}\text { Standard } \\
\text { error }\end{array}$} \\
\hline \multicolumn{7}{|c|}{ Rainfall for cultivation months one to four (millimeters) } \\
\hline$<250$ & -0.2495 & 0.0039 & $* * *$ & -0.2440 & 0.0039 & $* * *$ \\
\hline $250-300$ & -0.0893 & 0.0031 & $* * *$ & -0.0865 & 0.0031 & $* * *$ \\
\hline $300-350$ & -0.0432 & 0.0026 & $* * *$ & -0.0417 & 0.0026 & $* * *$ \\
\hline $350-400$ & -0.0197 & 0.0025 & $* * *$ & -0.0188 & 0.0025 & *** \\
\hline $450-500$ & -0.0013 & 0.0028 & & -0.0017 & 0.0027 & \\
\hline $500-600$ & -0.0192 & 0.0028 & $* * *$ & -0.0215 & 0.0028 & *** \\
\hline$>600$ & -0.1760 & 0.0039 & $* * *$ & -0.1767 & 0.0039 & *** \\
\hline \multicolumn{7}{|c|}{ Mean daily maximum temperature for warmest month, cultivation months two to four $\left({ }^{\circ} \mathrm{C}\right)$} \\
\hline$<27$ & -0.0347 & 0.0033 & $* * *$ & -0.0308 & 0.0033 & $* * *$ \\
\hline $27-28$ & 0.0106 & 0.0030 & $* * *$ & 0.0135 & 0.0030 & *** \\
\hline $29-30$ & -0.0255 & 0.0026 & $* * *$ & -0.0230 & 0.0026 & *** \\
\hline $30-31$ & -0.0712 & 0.0028 & $* * *$ & -0.0680 & 0.0028 & *** \\
\hline $31-32$ & -0.1483 & 0.0032 & $* * *$ & -0.1460 & 0.0032 & $* * *$ \\
\hline $32-33$ & -0.2616 & 0.0037 & $* * *$ & -0.2593 & 0.0037 & *** \\
\hline $33-34$ & -0.3554 & 0.0047 & $* * *$ & -0.3567 & 0.0047 & $* * *$ \\
\hline $34-35$ & -0.4627 & 0.0060 & *** & -0.4679 & 0.0060 & *** \\
\hline$>35$ & -0.5711 & 0.0070 & $* * *$ & -0.5800 & 0.0070 & $* * *$ \\
\hline $\begin{array}{l}\text { Year (time trend) } \\
\text { Log of expected maize }\end{array}$ & 0.0163 & 0.0001 & *** & 0.0171 & 0.0001 & *** \\
\hline price & & & & 0.0559 & 0.0036 & $* * *$ \\
\hline Intercept & -23.455 & 0.1675 & $* * *$ & -25.123 & 0.1980 & *** \\
\hline
\end{tabular}

Source: Authors.

Notes: The omitted categories are $400-450$ millimeters of rain and $28-29{ }^{\circ} \mathrm{C}$. $* * *$ significant at $1 \%$ level; $* *$ significant at $5 \%$ level; * significant at $10 \%$ level.

The results show that maize yield peaks at between 400 and 450 millimeters of rainfall in the first four months of the growing period, and that yield peaks when the mean daily maximum temperature of the second to fourth months of the growing period is between $27{ }^{\circ} \mathrm{C}$ and $28^{\circ} \mathrm{C}$. Over the observed range of temperatures and rainfall, the variation of yield due to precipitation is much smaller than that due to temperature. 
In addition to noting that the price elasticity of rainfed maize yield is 5.59 percent, we also see that the rate of yield growth between 1980 and 2010 after controlling for prices and weather is in the range of 1.63 percent to 1.71 percent per year. A growth rate of 1.63 percent per year would result in yield growth of 63.1 percent over a 30 -year period. This is how much yield would be expected to grow without any changes in climate. Our analysis is not able to distinguish the various contributions to that growth, which likely include technology embodied in seed development, changes in cultivation practices of farmers, and $\mathrm{CO}_{2}$ fertilization of maize.

Table 3.2 shows the results of a third regression, similar to Regression 2 of Table 3.1, but now with interaction terms between the time trend and each categorical variable for rainfall and temperature. The first columns are for the noninteracted terms and the last are for the interacted terms. We note that all of the parameter estimates for the interacted terms are statistically significant at the 1 percent levelexcept for those in the 450-to-500-millimeter rainfall range, which is next to the omitted category of 400 450 millimeters, and not expected to be very different than the neighboring category. We note that for the temperature interaction terms, the parameters get quantitatively larger as the temperature ranges go higher, suggesting that yield is improving faster at higher temperatures. Similarly, for rainfall interaction terms, parameters get quantitatively larger as precipitation levels decrease.

Table 3.2 Regression results for log of rainfed maize yield with interaction of time trend and weather variables

\begin{tabular}{|c|c|c|c|c|c|c|}
\hline \multirow[b]{2}{*}{ Variable } & \multicolumn{3}{|c|}{$\begin{array}{c}\text { Noninteracted } \\
\text { variable }\end{array}$} & \multicolumn{3}{|c|}{$\begin{array}{l}\text { Variables with time } \\
\text { trend interaction }\end{array}$} \\
\hline & Coefficient & \multicolumn{2}{|c|}{$\begin{array}{l}\text { Standard } \\
\text { error }\end{array}$} & Coefficient & \multicolumn{2}{|c|}{$\begin{array}{l}\text { Standard } \\
\text { error }\end{array}$} \\
\hline \multicolumn{7}{|c|}{ Rainfall for cultivation months one to four (millimeters) } \\
\hline$<250$ & -10.0669 & 0.8287 & $* * *$ & 0.0049 & 0.0004 & *** \\
\hline $250-300$ & -9.5030 & 0.6766 & $* * *$ & 0.0047 & 0.0003 & *** \\
\hline $300-350$ & -3.1055 & 0.5727 & $* * *$ & 0.0015 & 0.0003 & $* * *$ \\
\hline $350-400$ & -2.1574 & 0.5570 & $* * *$ & 0.0011 & 0.0003 & $* * *$ \\
\hline $450-500$ & 0.6049 & 0.6039 & & -0.0003 & 0.0003 & \\
\hline $500-600$ & 2.9672 & 0.5820 & $* * *$ & -0.0015 & 0.0003 & *** \\
\hline$>600$ & 5.4258 & 0.8311 & $* * *$ & -0.0028 & 0.0004 & $* * *$ \\
\hline \multicolumn{7}{|c|}{ Mean daily maximum temperature for warmest month, cultivation months two to four $\left({ }^{\circ} \mathrm{C}\right)$} \\
\hline$<27$ & -9.5899 & 0.7783 & *** & 0.0048 & 0.0004 & *** \\
\hline $27-28$ & -2.2371 & 0.6747 & *** & 0.0011 & 0.0003 & *** \\
\hline 29-30 & -2.1305 & 0.5575 & $* * *$ & 0.0011 & 0.0003 & *** \\
\hline $30-31$ & -5.3545 & 0.5759 & $* * *$ & 0.0026 & 0.0003 & $* * *$ \\
\hline $31-32$ & -10.0770 & 0.6132 & $* * *$ & 0.0050 & 0.0003 & *** \\
\hline $32-33$ & -10.0201 & 0.7063 & $* * *$ & 0.0049 & 0.0004 & $* * *$ \\
\hline $33-34$ & -10.0664 & 0.8219 & $* * *$ & 0.0049 & 0.0004 & $* * *$ \\
\hline $34-35$ & -12.7247 & 1.0282 & $* * *$ & 0.0061 & 0.0005 & *** \\
\hline$>35$ & -16.2374 & 1.1017 & $* * *$ & 0.0079 & 0.0006 & $* * *$ \\
\hline Year (time trend) & 0.0137 & 0.0003 & $* * *$ & & & \\
\hline $\begin{array}{l}\text { Log of expected maize } \\
\text { price }\end{array}$ & 0.0637 & 0.0036 & $* * *$ & & & \\
\hline Intercept & -18.3495 & 0.5407 & $* * *$ & & & \\
\hline
\end{tabular}

Source: Authors.

Notes: The omitted categories are $400-450$ millimeters of rain and $28-29^{\circ} \mathrm{C}$, as well as the interaction of the time trend with those two categories. The results in this table are from one regression, with the variables interacted with time trend reported in the last two columns. *** significant at $1 \%$ level; ** significant at $5 \%$ level; * significant at $10 \%$ level. 
Table 3.2 shows a similar price elasticity for maize to what was reported in Table 3.1, but the rate of yield growth after controlling for price and weather is lower than in Table 3.1. This shows that growth in total factor productivity is difficult to separate from adaptation to climate and weather stress, since the growth rate would have been reported as being much higher if the omitted categories in the regression had been temperatures in the $34-35^{\circ} \mathrm{C}$ range and rainfall below 250 millimeters instead of categories that were near the peak of productivity and that had slower growth rates.

To better interpret the effect on yield from the parameter estimates, we show in Table 3.3 the yield multipliers of each category of rainfall and temperature. The multipliers from Regressions 1 and 2 were found simply by exponentiating the values reported in Table 3.1, since the dependent variable was the natural $\log$ of yield. The multipliers from Regression 3 are in two columns of Table 3.3, one computed using 1980 as the time trend, and the other using 2010.

Table 3.3 Yield impacts relative to omitted categories

\begin{tabular}{|c|c|c|c|c|c|}
\hline \multirow[b]{3}{*}{ Variable } & \multirow{3}{*}{$\begin{array}{r}\text { Regression } 1 \\
\% \text { of yield of } \\
\text { omitted } \\
\text { category }\end{array}$} & \multirow{3}{*}{$\begin{array}{r}\text { Regression } 2 \\
\% \text { of yield of } \\
\text { omitted } \\
\text { category }\end{array}$} & \multicolumn{3}{|c|}{ Regression 3} \\
\hline & & & \multicolumn{2}{|c|}{$\begin{array}{l}\% \text { of yield of } \\
\text { omitted category }\end{array}$} & \multirow{2}{*}{$\begin{array}{c}\% \text { increase in } \\
\text { relative yield, } \\
1980-2010 \\
\end{array}$} \\
\hline & & & 1980 & 2010 & \\
\hline \multicolumn{6}{|c|}{ Rainfall for cultivation months one to four (millimeters) } \\
\hline$<250$ & 77.9 & 78.4 & 73.5 & 85.2 & 15.9 \\
\hline $250-300$ & 91.5 & 91.7 & 85.8 & 98.8 & 15.2 \\
\hline $300-350$ & 95.8 & 95.9 & 93.8 & 98.2 & 4.7 \\
\hline $350-400$ & 98.1 & 98.1 & 96.6 & 99.7 & 3.3 \\
\hline $400-450$ & 100.0 & 100.0 & 100.0 & 100.0 & 0.0 \\
\hline $450-500$ & 99.9 & 99.8 & 100.4 & 99.5 & -0.9 \\
\hline $500-600$ & 98.1 & 97.9 & 100.4 & 95.9 & -4.4 \\
\hline \multicolumn{6}{|c|}{$\begin{array}{l}\text { Mean daily maximum temperature for warmest month, cultivation months two to } \\
\text { four }\left({ }^{\circ} \mathrm{C}\right)\end{array}$} \\
\hline$<27$ & 96.6 & 97.0 & 89.7 & 103.6 & 15.4 \\
\hline $27-28$ & 101.1 & 101.4 & 99.9 & 103.3 & 3.4 \\
\hline $28-29$ & 100.0 & 100.0 & 100.0 & 100.0 & 0.0 \\
\hline $29-30$ & 97.5 & 97.7 & 96.0 & 99.1 & 3.2 \\
\hline $30-31$ & 93.1 & 93.4 & 89.6 & 97.0 & 8.3 \\
\hline $31-32$ & 86.2 & 86.4 & 80.1 & 93.0 & 16.1 \\
\hline $32-33$ & 77.0 & 77.2 & 72.0 & 83.4 & 15.8 \\
\hline $33-34$ & 70.1 & 70.0 & 65.4 & 75.7 & 15.7 \\
\hline $34-35$ & 63.0 & 62.6 & 57.4 & 69.1 & 20.2 \\
\hline$>35$ & 56.5 & 56.0 & 50.8 & 64.3 & 26.6 \\
\hline
\end{tabular}

Source: Authors.

Note: Regression 3 includes a log of maize price, as well as interaction terms of weather and time trend.

We note from the multipliers for Regression 3 that maize yields in the United States grew 20.2 percent faster between 1980 and 2010 when the mean daily maximum temperature for the warmest month was in the $34-35^{\circ} \mathrm{C}$ range compared to when it was in the $28-29^{\circ} \mathrm{C}$ range. Similar results are noted for other temperatures above $29^{\circ} \mathrm{C}$, and particularly for those above $31^{\circ} \mathrm{C}$. This is an important finding, because Schlenker and Roberts (2009) suggested that there has been little adaptation to heat by maize. It also suggests that studies using either days or growing degree days above a threshold temperature (Miao, 
Khanna, and Huang 2015; Schlenker and Roberts 2009; Lobell et al. 2011) as their indicator for heat stress may need to test for shifts in the threshold temperature when multiple years of data are used.

We also see from Table 3.3, Regression 3, that US maize has become more tolerant of lower rainfall levels, with yields growing 15.9 percent faster between 1980 and 2010 when rainfall is below 250 millimeters in the first four months of the growing period compared with when it is between 400 and 450 millimeters (the optimal amount of rainfall). It has also grown less tolerant of higher rainfall levels compared with the 400-to-450-millimeter range.

It is not clear why maize seems to be improving in its tolerance for higher temperatures and lower moisture. We performed a number of tests to see whether some of the yield data might reflect irrigated yields being improperly mixed with rainfed yields, but the results held up to such tests. 1 We suspect that much of the change in heat and low moisture tolerance is embedded in the seeds that are being developed. An additional contributing factor might be the growth in the use of no-till cultivation.

Between 1972 and 2012, no-till acreage grew 2.3 percent annually for all US crops Dobberstein 2014). Between 1996 and 2010, no-till maize acreage rose from 12.6 million acres to 19.5 million acres (USDA-ERS 2015). One study indicates that high air temperatures near the ground are reduced when using no-till maize, making the micro-environment near the ground more hospitable to maize growth (Davin et al. 2014).

One other possibility to consider as to why maize seems to be growing in its tolerance of heat is that $\mathrm{CO}_{2}$ fertilization might be more beneficial to maize at higher temperatures than at lower temperatures, though this would contradict the findings of other studies (Tubiello, Soussana, and Howden 2007; Caldwell, Britz, and Mirecki 2005; Baker 2004; Thomas et al. 2003). Some studies suggest that higher $\mathrm{CO}_{2}$ levels may help alleviate drought pressures (Tubiello, Soussana, and Howden 2007; Morgan et al. 2004), which could help explain our findings concerning the improved tolerance to lower rainfall levels between 1980 and 2010 .

Despite both heat tolerance and low-rainfall tolerance increasing between 1980 and 2010, even at the end of the period there are considerable yield reductions for low rainfall and high temperatures. This means that despite apparent significant improvement, climate change will still adversely affect agriculture.

\footnotetext{
${ }^{1}$ One such test involved extracting agricultural census data for 1997, 2002, 2007, and 2012. Any county that had any acreage of maize that was irrigated in any of those years was eliminated from the regression. The qualitative results held for both precipitation and temperature, and the statistical significance of all temperature interaction terms remained at the 1 percent level, and the two driest rainfall categories also maintained statistical significance at the 1 percent level.
} 


\section{ESTIMATING CLIMATE IMPACT ON MAIZE}

We took the parameters from Regression 1, Table 3.1, and used a quadratic regression to extend them beyond the temperature and precipitation limits of the original parameter estimates. Then we applied baseline climate data and climate projections for 2050 using data from Müller and Robertson (2014; Hempel et al. 2013), and therefore also similar to that of Rosenzweig et al. (2014). The results are presented in Table 4.1.

The regression predictions for the United States are closest to those of the PEGASUS model in the GGCMI. The EPIC model also had similar results for the United States, except for the GFDL GCM. For the global predictions, the regression results were again closest to those of the PEGASUS model. Because of the similarity between the regression predictions and those of the PEGASUS model for both the United States and the world, this suggests that using US yield regression results with a quadratic estimator to extend the results to a wider temperature and precipitation range may provide an acceptable methodology to predict the impact of climate change on many types of crops around the world. More testing would need to be done before fully implementing such a methodology.

For the estimations of Müller and Robertson (2014) without $\mathrm{CO}_{2}$ fertilization, the DSSAT model was closer to the global prediction for the HadGEM GCM, but the LPJmL model was closer for the IPSL GCM.

Table 4.1 Projected yield changes from regression estimates, 2000 to 2050

\begin{tabular}{lrrrc}
\hline Region & GFDL & HadGEM & IPSL & MIROC \\
\hline United & & & & \\
States & -9.8 & -42.8 & -22.9 & -36.0 \\
Global & -8.6 & -28.2 & -18.5 & -23.9 \\
\hline
\end{tabular}

Source: Author.

Note: The baseline period yields were rebased to yields from SPAM2005 (You and Wood 2006; You, Wood, and WoodSichra 2006, 2009, 2014). 


\section{CONCLUDING REMARKS}

Using a regression approach to historical agricultural data is a promising avenue for the future of modeling climate impacts. In our analysis, we discovered a number of important results. First, at least in the case of rainfed maize in the United States, prices can be ignored when trying to compute weather impacts on yield. Second, US rainfed maize is becoming more tolerant of high temperatures and low precipitation. Third, we seemed to validate the most pessimistic of all of the crop model estimates from the GGCMI (Rosenzweig et al. 2014) for rainfed maize.

Possibly most important of all, we began examining the validity of using one country's agricultural and weather data not only to predict climate impact for that country but to extrapolate predictions globally. Much remains to be done in this work, but if it bears fruit, the results could be used to get better estimates of the impact of climate change on many crops.

A novel additional use of the methodology is that it may allow us to estimate historical growth in total factor productivity for specific crops and countries. That is, if weather effects can be controlled for (because the parameters were already measured from one country's yield data), then using the parameter estimates together with another country's yield and weather data would allow us to estimate growth in total factor productivity for that other country for that crop, even if the other country did not have any cross-sectional yield data for subnational units, but only for itself for multiple years. 


\section{REFERENCES}

Baker, J. T. 2004. "Yield Responses of Sourthern US Rice Cultivars to $\mathrm{CO}_{2}$ and Temperature." Agricultural and Forest Meteorology 122: 129-137.

Barchart. 2015. Corn futures historical data. Accessed August 17. www.barchart.com/commodityfutures/ Corn_Futures/ZC.

Bondeau, A., P. C. Smith, S. Zaehle, S. Schaphoff, W. Lucht, W. Cramer, D. Gerten, H. Lotze-Campen, C. Müller, M. Reichstein, and B. Smith. 2007. "Modelling the Role of Agriculture for the 20th Century Global Terrestrial Carbon Balance." Global Change Biology 13 (3): 679-706.

Bouwman, A. F., T. Kram, T. Klein, and K. Goldewijk, eds. 2006. Integrated Modelling of Global Environmental Change. An Overview of IMAGE 2.4. The Hague: PBL Netherlands Environmental Assessment Agency.

Caldwell, C. R., S. J. Britz, and R. M. Mirecki. 2005. "Effect of Temperature, Elevated Carbon Dioxide, and Drought during Seed Development on the Isoflavone Content of Dwarf Soybean [Glycine max (L.)] Grown in Controlled Environments." Journal of Agricultural and Food Chemistry 53: 1125-1129.

Choi, J.-S., and P. G. Helmberger. 1993. "How Sensitive Are Crop Yields to Price Changes and Farm Programs?" Journal of Agricultural and Applied Economics 25: 237-244.

Collins, W. J., N. Bellouin, M. Doutriaux-Boucher, N. Gedney, P. Halloran, T. Hinton, J. Hughes, C. D. Jones, M. Joshi, S. Liddicoat, G. Martin, F. O'Connor, J. Rae, C. Senior, S. Sitch, I. Totterdell, A. Wiltshire, and S. Woodward. 2011. "Development and Evaluation of an Earth-System Model-HadGEM2." Geoscientific Model Development 4: 1051-1075.

Davin, E. L., S. I. Seneviratne, P. Ciais, A. Olioso, and T. Wang. 2014. "Preferential Cooling of Hot Extremes from Cropland Albedo Management." Proceedings of the National Academy of Sciences of the United States of America 111 (27): 9757-9761. doi: 10.1073/pnas.1317323111.

Dell, M., B. F. Jones, and B. A. Olken. 2014. "What Do We Learn from the Weather? The New Climate-Economy Literature." Journal of Economic Literature 52 (3): 740-798. http://dx.doi.org/10.1257/jel.52.3.740.

Deryng, D., W. J. Sacks, C. C. Barford, and N. Ramankutty. 2011. "Simulating the Effects of Climate and Agricultural Management Practices on Global Crop Yield." Global Biogeochemical Cycles 25 (2).

Dobberstein, J. 2014. "No-Till Movement in U.S. Continues to Grow.” No-Till Farmer. Accessed August 24, 2015. www.no-tillfarmer.com/articles/489-no-till-movement-in-us-continues-to-grow.

Dufresne, J. L., and Coauthors. 2013. "Climate Change Projections Using the IPSL-CM5 Earth System Model: From CMIP3 to CMIP5.” Climate Dynamics 40 (9-10): 2123-2165.

Dunne, J. P., J. G. John, A. J. Adcroft, S. M. Griffies, R. W. Hallberg, E. Shevliakova, R. J. Stouffer, W. Cooke, K. A. Dunne, M. J. Harrison, J. P. Krasting, S. L. Malyshev, P. C. D. Milly, P. J. Phillipps, L. T. Sentman, B. L. Samuels, M. J. Spelman, M. Winton, A. T. Wittenberg, and N. Zadeh. 2012. "GFDL's ESM2 Global Coupled Climate-Carbon Earth System Models Part I: Physical Formulation and Baseline Simulation Characteristics." Journal of Climate 25 (19): 6646-6665.

Dunne, J. P., J. G. John, E. Shevliakova, R. J. Stouffer, J. P. Krasting, S. L. Malyshev, P. C. D. Milly, L. T. Sentman, A. J. Adcroft, W. Cooke, K. A. Dunne, S. M. Griffies, R. W. Hallberg, M. J. Harrison, H. Levy, A. T. Wittenberg, P. J. Phillips, and N. Zadeh. 2013. "GFDL's ESM2 Global Coupled Climate-Carbon Earth System Models. Part II: Carbon System Formation and Baseline Simulation Characteristics." Journal of Climate 26 (7): 2247-2267.

Elliott, J., M. Glotter, N. Best, D. Kelly, M. Wilde, and I. Foster. 2013. "The Parallel System for Integrating Impact Models and Sectors (pSIMS)." Proceedings of the Conference on Extreme Science and Engineering Discovery Environment: Gateway to Discovery (XSEDE '13). Association for Computing Machinery 21: $1-8$.

Elliott, J., C. Müller, D. Deryng, J. Chryssanthacopoulos, K. J. Boote, M. Büchner, I. Foster, M. Glotter, J. Heinke, T. Iizumi, R. C. Izaurralde, N. D. Mueller, D. K. Ray, C. Rosenzweig, A. C. Ruane, and J. Sheffield. 2015. 
"The Global Gridded Crop Model Intercomparison: Data and Modeling Protocols for Phase 1 (v1.0)." Geoscientific Model Development 8: 261-277. doi: 10.5194/gmd-8-261-2015.

Fader, M., S. Rost, C. Müller, A. Bondeau, and D. Gerten. 2010. "Virtual Water Content of Temperate Cereals and Maize: Present and Potential Future Patterns." Journal of Hydrology 384 (3-4): 218-231.

FAO (Food and Agriculture Organization of the United Nations). 2014. FAOSTAT. Rome. http://faostat.fao.org.

Fischer, G., M. Shah, and H. Velthuizen. 2002. Climate Change and Agricultural Vulnerability. Vienna: International Institute for Applied Systems Analysis.

Gassman, P. W., J. R. Williams, V. W. Benson, R. C. Izaurralde, L. M. Hauck, C. A. Jones, J. D. Atwood, J. R. Kiniry, and J. D. Flowers. 2004. "Historical Development and Applications of the EPIC and APEX Models." Presented at the 2004 ASAE/CSAE Annual International Meeting, Ottawa, Ontario, Canada, August 1-4. Meeting paper 042097. www.card.iastate.edu.

Hempel, S., K. Frieler, L.Warszawski, J. Schewe, and F. Piontek. 2013. “A Trend-Preserving Bias Correction—The ISI-MIP Approach.” Earth System Dynamics 4: 219-236.

Iversen, T. M. Bentsen, I. Bethke, J. B. Debernard, A. Kirkevåg, Ø. Seland, H. Drange, J. E. Kristjansson, I. Medhaug, M. Sand, and I. A. Seierstad. 2013. "The Norwegian Earth System Model, NorESM1-M. Part 2: Climate Response and Scenario Projections." Geoscientific Model Development 6: 389-415.

Izaurralde, R. C., J. R. Williams, W. B. McGill, N. J. Rosenberg, and M. C. Quiroga Jakas. 2006. "Simulating Soil C Dynamics with EPIC: Model Description and Testing against Long-Term Data." Ecological Modelling 192 (3-4): 362-384.

Jones, J. W., G. Hoogenboom, C. H. Porter, K. J. Boote, W. D. Batchelor, L. A. Hunt, P. W. Wilkens, U. Singh, A. J. Gijsman, and J. T. Ritchie. 2003. "The DSSAT Cropping System Model." European Journal of Agronomy 18 (3-4): 235-265.

Leemans, R., and A. M. Solomon. 1993. "Modeling the Potential Change in Yield and Distribution of the Earth's Crops under a Warmed Climate." Climate Research 3: 79-96.

Lindeskog, M., A. Arneth, A. Bondeau, A. Waha, J. W. Seaquist, S. Olin, and B. Smith. 2013. "Implications of Accounting for Land Use in Simulations of Ecosystem Services and Carbon Cycling in Africa." Earth System Dynamics Discussions 4: 235-278.

Liu, J., J. R. Williams, A. J. B. Zehnder, H. Yang. 2007. “GEPIC—Modeling Wheat Yield and Crop Water Productivity with High Resolution on a Global Scale.” Agricultural Systems 94 (2): 478-493.

Lobell, D. B., M. Bänziger, C. Magorokosho, and B. Vivek. 2011. "Nonlinear Heat Effects on African Maize as Evidenced by Historical Yield Trials." Nature Climate Change 1 (April): 42-45.

Lobell, D. B., and M. B. Burke. 2010. "On the Use of Statistical Models to Predict Crop Yield Responses to Climate Change." Agricultural and Forest Meteorology 150 (11): 1443-1452.

Lobell, D. B., W. Schlenker, and J. Costa-Roberts. 2011. "Climate Trends and Global Crop Production since 1980." Science 333 (6042): 616-620.

Martin, G. M., N. Bellouin, W. J. Collins, I. D. Culverwell, P. R. Halloran, S. C. Hardiman, T. J. Hinton, C. D. Jones, R. E. McDonald, A. J. McLaren, F. M. O'Connor, and M. J. Roberts. 2011. "The HadGEM2 Family of Met Office Unified Model Climate Configurations." Geoscientific Model Development 4: 723-757.

Miao, R., M. Khanna, and H. Huang. 2015. "Responsiveness of Crop Yield and Acreage to Prices and Climate." American Journal of Agricultural Economics. . doi: 10.1093/ajae/aav025.

Morgan, J. A., D. E. Pataki, C. Korner, H. Clark, S. J. Del Grosso, J. M. Grunzweig, A. K. Knapp, A. R. Mosier, P. C. D. Newton, and P. A. Niklaus, J. B. Nippert, R. S. Nowak, W. J. Parton, H. W. Polley, and M. R. Shaw. 2004. "Water Relations in Grassland and Desert Ecosystems to Elevated Atmospheric $\mathrm{CO}_{2}$." Oecologia 140: $11-25$.

Müller, C., and R. D. Robertson. 2014. "Projecting Future Crop Productivity for Global Economic Modeling." Agricultural Economics 45 (1): 37-50. doi: 10.1111/agec.12088. 
Nelson, G. C., M. W. Rosegrant, J. Koo, R. Robertson, T. Sulser, T. Zhu, C. Ringler, S. Msangi, A. Palazzo, M. Batka, M. Magalhaes, R. Valmonte-Santos, M. Ewing, and D. Lee. 2009. Climate Change: Impact on Agriculture and Costs of Adaptation. Food Policy Report. Washington, DC: International Food Policy Research Institute. doi: 10.2499/0896295354.

Nelson, G. C., M. W. Rosegrant, A. Palazzo, I. Gray, C. Ingersoll, R. Robertson, S. Tokgoz, T. Zhu,T. B. Sulser, C. Ringler, S. Msangi, and L. You. 2010. Food Security, Farming, and Climate Change to 2050: Scenarios, Results, Policy Options. Washington, DC: International Food Policy Research Institute. www.ifpri.org/publication/food-security-farming-and-climate-change-2050.

Nelson, G. C., H. Valin, R. D. Sands, P. Havlík, H. Ahammad, D. Deryng, J. Elliott, S. Fujimori, T. Hasegawa, E. Heyhoe, P. Kyle, M. von Lampe, H. Lotze-Campen, D. Mason D’Croz, H. van Meijl, D. van der Mensbrugghe, C. Müller, A. Popp, R. Robertson, S. Robinson, E. Schmid, C. Schmitz, A. Tabeau, and D. Willenbockel. 2013. "Climate Change Effects on Agriculture: Economic Responses to Biophysical Shocks." Proceedings of the National Academy of Sciences of the United States of America 111 (9): 32743279.

Nelson, G. C., D. van der Mensbrugghe, H. Ahammad, E. Blanc, K. Calvin, T. Hasegawa, P. Havlik, E. Heyhoe, P. Kyle, H. Lotze-Campen, M. von Lampe, D. Mason d'Croz, H. van Meijl, C. Müller, J. Reilly, R. Robertson, R. D. Sands, C. Schmitz, A. Tabeau, K. Takahashi, H. Valin, and D. Willenbockel. 2014. "Agriculture and Climate Change in Global Scenarios: Why Don't the Models Agree." Agricultural Economics 45 (1): 85-101. doi: 10.1111/agec.12091.

Rosegrant, M. W., M. Agcaoili-Sombilla, and N. D. Perez. 1995. Global Food Projections to 2020: Implications for Investment. Food, Agriculture, and the Environment Discussion Paper 5. Washington, DC: International Food Policy Research Institute. www.ifpri.org/sites/default/files/publications/vp5.pdf.

Rosenzweig, C., J. Elliott, D. Deryng, A. C. Ruane, C. Müller, A. Arneth, K. J. Boote, C. Folberth, M. Glotter, N. Khabarov, K. Neumann, F. Piontek, T. A. M. Pugh, E. Schmid, E. Stehfest, H. Yang, and J. W. Jones. 2014. "Assessing Agricultural Risks of Climate Change in the 21st Century in a Global Gridded Crop Model Intercomparison." Proceedings of the National Academy of Sciences of the United States of America 111 (9): 3268-3273. doi: 10.1073/pnas.1222463110.

Rosenzweig, C., and M. L. Parry. 1994. "Potential Impacts of Climate Change on World Food Supply.” Nature 367: 133-138.

Ruane, A. C., R. Goldberg, and J. Chryssanthacopoulos. 2015. "Climate Forcing Datasets for Agricultural Modeling: Merged Products for Gap-Filling and Historical Climate Series Estimation.” Agricultural and Forest Meteorology 200: 233-248.

Sacks, W. J., D. Deryng, J. A. Foley, and N. Ramankutty. 2010. “Crop Planting Dates: An Analysis of Global Patterns.” Global Ecology and Biogeography 19: 607-620. doi: 10.1111/j.1466-8238.2010.00551.x.

Sakamoto, T. T., Y. Komuro, T. Nishimura, M. Ishii, H. Tatebe, H. Shiogama, A. Hasegawa, T. Toyoda, M. Mori, T. Suzuki, Y. Imada, T. Nzawa, K. Takata, T. Mochizuki, K. Ogochi, S. Emori, H. Hasumi, and M. Kimoto. 2012. "MIROC4h-A New High-Resolution Atmosphere-Ocean Coupled General Circulation Model." Journal of the Meteorological Society of Japan. Ser. II 90: 325-359.

Schlenker, W., and M. J. Roberts. 2009. "Nonlinear Temperature Effects Indicate Severe Damages to U.S. Crop Yields under Climate Change." Proceedings of the National Academy of Sciences of the United States of America 106 (37): 15594-15598.

Smith, B., I. C. Prentice, and M. T. Sykes. 2001. "Representation of Vegetation Dynamics in the Modeling of Terrestrial Ecosystems: Comparing Two Contrasting Approaches within European Climate Space." Global Ecology and Biogeography 10 (6): 621-637.

Thomas, J. M. G, K. J. Boote, L. H. Allen Jr, M. Gallo-Meagher, and J. M. Davis. "Elevated Temperature and Carbon Dioxide Effects on Soybean Seed Composition and Transcript Abundance." 2003. Crop Science 43: 1548-1557. 
Tubiello, F. N., J.-F. Soussana, and S. M. Howden. 2007. "Crop and Pasture Response to Climate Change." Proceedings of the National Academy of Sciences of the United States of America 104 (50): 19686-19690. doi: 10.1073/pnas.0701728104.

USDA-ERS (US Department of Agriculture Economic Research Service). 2015. No-till Corn Data. Accessed August 25. www.ers.usda.gov/data-products/arms-farm-financial-and-crop-production-practices/tailoredreports-crop-production-practices.aspx\#P6a16f3600cf948d687be725b4ade1748 5 66iT0R0T0R0x1.

USDA-NASS (US Department of Agriculture, National Agricultural Statistics Service). 2015. County crop statistics. Accessed May 8. http://quickstats.nass.usda.gov/.

Waha, K., L. G. J. van Bussel, C. Müller, and A. Bondeau. 2012. "Climate-Driven Simulation of Global Crop Sowing Dates." Global Ecology and Biogeography 21 (2): 247-259.

Williams, J. R. 1995. “The EPIC Model.” In Computer Models of Watershed Hydrology, edited by V. P. Singh, 909-1000. Littleton, CO, US: Water Resources Publications.

Williams, J. R., and A. N. Sharpley. 1990. EPIC-Erosion/Productivity Impact Calculator. Technical Bulletin 1768. Springfield, VA, US: US Department of Agriculture Agricultural Research Service.

You, L., and S. Wood. 2006. “An Entropy Approach to Spatial Disaggregation of Agricultural Production.” Agricultural Systems 90 (1-3): 329-347.

You, L., S. Wood, and U. Wood-Sichra. 2006. "Generating Global Crop Distribution Maps: From Census to Grid." Paper presented at the International Association of Agricultural Economists Conference, Brisbane, Australia, August 11-18.

2009. "Generating Plausible Crop Distribution and Performance Maps for Sub-Saharan Africa Using a Spatially Disaggregated Data Fusion and Optimization Approach.” Agricultural Systems 99 (2-3): 126140 .

. 2014. "Generating Global Crop Distribution Maps: From Census to Grid.” Agricultural Systems 127 (2014): 53-60. 




\section{RECENT IFPRI DISCUSSION PAPERS}

\section{For earlier discussion papers, please go to www.ifpri.org/pubs/pubs.htm\#dp. All discussion papers can be downloaded free of charge.}

1484. Customary tenure and innovative measures of safeguarding land rights in Africa: The community land initiative (iniciativa de terras comunitárias) in Mozambique. Hosaena Ghebru, Raul Pitoro, and Sileshi Woldeyohannes, 2015.

1483. The International Model for Policy Analysis of Agricultural Commodities and Trade (IMPACT): Model description for version 3. Sherman Robinson, Daniel Mason-D’Croz, Shahnila Islam, Timothy B. Sulser, Richard Robertson, Tingju Zhu, Arthur Gueneau, Gauthier Pitois, and Mark Rosegrant, 2015.

1482. Enhancing food security in South Sudan: The role of public food stocks and cereal imports. Paul A. Dorosh, Shahidur Rashid, Abigail Childs, and Joanna van Asselt, 2015.

1481. Gender, headship, and the life cycle: Landownership in four Asian countries. Kathryn Sproule, Caitlin Kieran, Agnes Quisumbing, and Cheryl Doss, 2015.

1480. The food-energy-water security nexus: Definitions, policies, and methods in an application to Malawi and Mozambique. Thea Nielsen, Franziska Schünemann, Emily McNulty, Manfred Zeller, Ephraim Nkonya, Edward Kato, Stefan Meyer, Weston Anderson, Tingju Zhu, Antonio Queface, and Lawrence Mapemba, 2015.

1479. The making of public investments: Champions, coordination, and characteristics of nutrition interventions, Tewodaj Mogues and Lucy Billings, 2015.

1478. The dynamics of smallholder marketing behavior: Explorations using Ugandan and Mozambican panel data. Bjorn Van Campenhout, 2015.

1477. Adjusting to external shocks in small open economies: The case of Honduras. Samuel Morley and Valeria Piñeiro, 2015.

1476. Drivers of growth in agricultural returns to scale: The hiring in of tractor services in the Terai of Nepal. Hiroyuki Takeshima, 2015

1475. The contribution of increased equity to the estimated social benefits from a transfer program: An illustration from PROGRESA. Harold Alderman, Jere R. Behrman, and Afia Tasneem, 2015.

1474. Reconstructing public expenditure data: Use of classification systems to better measure public spending in agriculture A Mozambique case study. Tewodaj Mogues, Leonardo Caceres, Francisco A. Fernandez, and Mariam B. Umarji, 2015.

1473. Agricultural insurance and the World Trade Organization. Joseph W. Glauber, 2015.

1472. Grain price and volatility transmission from international to domestic markets in developing countries. Francisco Ceballos, Manuel A. Hernandez, Nicholas Minot, and Miguel Robles, 2015.

1471. Policy changes in times of crisis: Evidence from the Arab Spatial Policy Analyzer. Jacopo Bordignon and Clemens Breisinger, 2015.

1470. Gender empowerment gaps in agriculture and children's well-being in Bangladesh. Hazel Jean L. Malapit, Esha Sraboni, Agnes R. Quisumbing, and Akhter Ahmed, 2015.

1469. Climate change adaptation in agriculture: Ex ante analysis of promising and alternative crop technologies using DSSAT and IMPACT. Sherman Robinson, Daniel Mason-D'Croz, Shahnila Islam, Nicola Cenacchi, Bernardo Creamer, Arthur Gueneau, Guy Hareau, Ulrich Kleinwechter, Khondoker Mottaleb, Swamikannu Nedumaran, Richard Robertson, Mark W. Rosegrant, Gbegbelegbe Sika, Timothy B. Sulser, Keith Wiebe, 2015.

1468. A proximity-based measure of industrial clustering. Jianqing Ruan and Xiaobo Zhang, 2015.

1467. Aspirations and the role of social protection: Evidence from a natural disaster in rural Pakistan. Katrina Kosec and Cecilia Hyunjung Mo, 2015.

1466. Addressing human capital development in public agriculture extension in southern Africa: Assessing Mozambique's experience. Hélder R. Gêmo and Kristin E. Davis, 2015.

1465. Microinsurance decisions: Gendered evidence from rural Bangladesh. Daniel J. Clarke and Neha Kumar, 2015.

1464. Institutions and market integration: The case of coffee in the Ethiopian commodity exchange. Manuel A. Hernandez, Shahidur Rashid, Solomon Lemma, and Tadesse Kuma, 2015.

1463. Happiness in the air: How does a dirty sky affect subjective well-being? Xin Zhang, Xiaobo Zhang, and Xi Chen, 2015. 


\section{INTERNATIONAL FOOD POLICY}

RESEARCH INSTITUTE

www.ifpri.org

IFPRI HEADQUARTERS

2033 K Street, NW

Washington, DC 20006-1002 USA

Tel.: +1-202-862-5600

Fax: +1-202-467-4439

Email: ifpri@cgiar.org 